\title{
A Study of Transformational Leadership in Bhutto's Reconciliation: Islam, Democracy and the West
}

\author{
Naheed P Malbari \\ Dr Javaid Laghari
}

\begin{abstract}
This paper is a qualitative study on Benazir Bhutto's "Reconciliation" and whether she can be assessed by her book as a transformational leader. Due to a dearth of formal leadership study of Eastern Muslim political leaders as well as their writings, this paper analyzes one such popular democratic leader. As transformational leadership has been of particular importance to researchers in recent years, this study has used Bass's analysis of Parameshwar's 2006 study as a premise of the paper. Four aspects of transformational leadership namely as leaders developing transcendental higher purposes and went beyond the ordinary by 1) exposing unresolved, disturbing human rights problems, 2) untangling false interpretations of the world; 3) breaking out of conventional solutions; and 4) making use of transcendental metaphors, have been used. The construct of Bhutto, challenging prevailing norms and notions of democracy, democratization and extremism in existence both within the Muslim world and the West has been reviewed keeping in mind the leadership premise.
\end{abstract}

Keywords: transformational leadership, reconciliation, extremism and democracy.

\section{Introduction}

'Political leaders create new possibilities in history.' Hargrove

\subsection{Background of the Study}

Very few political leaders the world over have written autobiographies or other works and to be a Muslim women to have written a contemporary political discourse which divides much of the Islamic world, gives us a preview of Benazir Bhutto's political ideology which has been a part of her since the judicial incarceration and ultimate hanging of her father and ex-prime minister Zulfiqar Ali Bhutto.

Just days prior to her death, Bhutto completed the manuscript of Reconciliation: Democracy, Islam and the West, which was published after her assassination. In the afterword, her immediate family stated that the Almighty gave Bhutto time to finish her incomplete manuscript when she survived the first assassination attempt in October only to succumb to the second one in December.

Reconciliation deals with not only Bhutto's last months before and after her return to Pakistan, but also with topics that are a burning issue in political circles these days. The chronology of the chapters is interesting if anything. The first deals with her return, but from the second chapter onwards, the political and religious elements and scenarios are discussed. In the 'Battle within Islam,' Bhutto discusses the rise of radicalism and then gives a historical cum religious background of how such forms of religious practice are against the true sentiments of Islamic thought. In 'Islam and democracy', 
Bhutto gives a compelling argument of how Islam does in fact support the institution of democracy. She then gives a brief outline of various Islamic countries which have battled the same problem of building democratic institutions. She gives 'the case of Pakistan,' and analyzes according to her viewpoint the lack of proper democratic institutions due to continuous hijacking by dictatorships and dictatorial regimes. Next Bhutto gives the East West debate with a detailed discussion of Huntington's 'clash of civilization thesis.' In it she gives compelling viewpoints of other theorists, academicians and religious scholars who oppose the thesis. Lastly, Bhutto gives her premise of how such a clash can and should be avoided and what needs to be done by both the Muslim world and the West.

Many reviews were written for the same. Yet if one reads her latest book, one realizes that many unique leadership abilities come to the forefront that allowed her to not only come to power twice but also to try for the third time which cost her her very life. Her idea of a progressive Muslim state is not a new one, yet, the concept of reconciliation between the east and west or between the Islamic world and the rest may be termed as enlightening, especially in the present political scenario, where many political analysts like Huntington etc. term such a concept as impossible and even improbable and dangerous to follow. It is important to state that in a previous study undertaken by me, called 'Transformational leadership and Mohtarma Benazir Bhutto,' Bhutto was analyzed taking into account what was written immediately after her death by western writers and whether their portrayal depicted her as a transformational leader. This book can be analyzed from the point of view of political theory, yet to study it from the point of view of leadership, to my knowledge, has not been done to date. Thus the study of leadership keeping her in mind and assessing her qualities may be of interest to many.

\subsection{Research problems and objectives}

To ascertain the fact that Mohtarma Benazir Bhutto can be regarded as a transformational leader.

- To what extent did Bhutto's last book Reconciliation: Islam, Democracy and the West, reaffirm the fact that Bhutto had the above leadership quality and to what extent did the book display incidences of Reconciliation which may make one regard Bhutto as a transformational leader.

- The researcher also wishes to explore the concept of Transformational Leadership and its application to Bhutto's achievements in the light of her book published after her demise.

- To see the extent to which the concept of transformational leadership as an important ideal is applicable for strong leadership.

\subsection{Significance and scope and limitation of the study}

The content used will be limited to the Reconciliation: Islam, Democracy and the West. Selected referencing from the book reviews on 'Reconciliation' is used. Apart from other references, transformational leadership in general has also been used in this study. Also background information on transformational leadership in my previous study has been employed with this research. The scope is not to give the viewpoints of the different authors Bhutto uses in her Reconciliation but to analyze her view points keeping in mind the premise of the study. A limitation of this study which needs to be mentioned here is that the goal is not to see Bhutto as a transformational leader per se but to understand whether her Reconciliation can be qualitatively analyzed for transformational leadership study. 


\subsection{Research Methodology}

Any research methodology fuses two aspects, namely, the theory that a researcher is going to follow and the method employed to conduct such a research.

\subsubsection{Theoretical Considerations}

This is a study of leadership and many theories of leadership are in existence. Thus the theoretical base of this study is transformational leadership as it applies to Bhutto. However, transformational leadership is not a new phenomenon and much analysis has been done. The concept that is to be employed in this research is one initiated by Parameshwar, 2006. Though many concepts of transformational leadership exist the latter would be used which will be discussed in detail later on.

\subsubsection{Methodological Considerations}

Methodology is based on four major aspects, namely, research purpose, research methods, research style and research strategy. All four components are part of this research. First and foremost, the research purpose is a descriptive one and therefore a descriptive format is used. It also fuses a number of disciplines namely leadership and narrative. Secondly, the research method deals with documents which are a secondary source of research. The style employed is based on one which deals with documentary/narrative research. Lastly, the research strategy used is a fusion of two, namely content and narrative analysis.

Content analysis is used keeping in mind the theory of Transformational Leadership. However, historically, content analysis is usually deemed to be a quantitative study and a neutral and objective way of gathering a specific kind of documentary data. The counting of specified items was deemed necessary (Berelson, 1952). So in this research a specific kind of method has been used. Ray Pawson's (1995) concept of content analysis has been taken, as it deals with a more comprehensive approach to the concept of content analysis. Thematic content analysis based on a leadership theme from the book 'Reconciliation' has been employed in this study.

Next narrative analysis has been employed as a research strategy. According to Roberts in Bryman (2004) narrative analysis researchers employ to understand 'their lives and the world around them.' It is used to refer to 'both an approach-one that emphasizes the examination of storied nature of human recounting of lives and events and to the source themselves.' This research hopes to determine to what extent did her 'Reconciliation' show aspects of transformational leadership of Bhutto. Also a particular model of narrative analysis has been employed. Riessman (2007) has given four models. This research employs thematic narrative analysis which emphasizes on what is said rather than how it is said. Such a documentary research may obtain knowledge of unexamined areas or re-examine questions. There can be a 'systematic and direct classification of data' and a systematic research can bring credibility and validity to the data (Marshall and Rossman, 2006).

\section{Transformational leadership: An overview}

Any study of Transformational Leadership needs to be assessed historically. Examples of such constructs include visionary leadership (Hunt, Boal, \& Dodge, 1999; Meindl, 1998) servant leadership (Pepper, 2003), spiritual leadership (Fry \& Malone, 2003), transcendental leadership (Cardona, 2000; Sanders, Hopkins, \& Geroy, 2002), moral leadership (Whetstone, 2002) ethical leadership (Treviño, Brown, \& Pincus-Hartman, 2003) and transformational leadership (Bass, 1990; Hunt \& Conger, 1999; Burns, 2003). The term though coined by Downton (1973), the concept first emerged with the work of Burns (1978) which linked the role between leadership and followership. Fast technological changes, great international competition, demographic labour changes etc., are some of the factors which brought to such a state (Stoner and Freeman, 1992). 
Second, leadership's theoretic base rested on the trait theory, behaviouristic theory of leaders and contingency theory of leadership which did not take into consideration "untypical" qualities of leaders which required a new leadership concept.

Therefore the transformational theory of leadership gave forth a new dimension to leadership studies. Burns' (1978) concept distinguished between two types of leadership, namely transactional and transformational. Transactional refers to the exchanges between leaders and followers, where as transformational is when the person engages with others and creates a connection which raises level of motivation in both the leader and the follower. Though initially used by Weber (1947) to describe bureaucratic, charismatic and traditional, leaders, House (1976) expanded and gave four phrases to define charismatic leadership showing them to be dominant and influential but also as confident with strong moral values. Later others gave similar but slightly differing conceptualizations of charisma (Conger and Kanungo, 1985; Sashkin, 1988; Shamir, House and Arthur, 1993).

Bass $(1985,1990)$ introduced a Formal Transformational Leadership Theory with charisma, vision, intellectual stimulation and inspiration as the main components. From then on a plethora of models came into being with leaders being led by values, vision, being social architects and modelling the way (Tichy and Devanna, 1986; Bennis and Nanus, 1985; Kouzes and Posner, 2002). Much research and studies were carried out as with Bass and Avolio (2000) giving the MLQ and others basing their studies on MLQ. Studies of transformational leadership stressed on acquisition integration (House and Aditiya, 1997; Yukl and Howell,1999) and organizational change (Bass, Avolio, Jung and Berson,2003; Nemanich and Keller, 2007).

Research has been undertaken in the context of organizations especially in areas of subordinate satisfaction with the leader and the perception of leaders effectiveness (Howell and Shamir,2005; Judge and Piccolo, 2004;). Some research has also been done with transformational leadership being studied with variables such as subordinate job satisfaction (Judge and Bono, 2000; Podsakoff, MacKensie and Bommer, 1996) and recently combining subordinate job satisfaction and acquisition acceptance in major organisations (Nemanich and Keller, 2007). Other research takes into consideration leader/follower relationship dimensions with charisma being an important variable (Campbell, Ward Sonnenfeld and Agle, 2008). However, the focus of this study has nothing to do with organizations but to do with political leadership which may transform the followers.

There has been some research done on political leadership but the focus of these studies have usually been on just one aspect namely charisma (Bligh, Kohles and Meindl 2004 a\&b; Emrich, Brower, Feldman and Garland, 2001; Mio, Riggio Levin and Reese, 2005; Seyranian and Bligh, 2007) and especially keeping in mind high profile leaders such as United States presidents (House, Spangler and Woycke, 1991). Most of such research has a quantitative analysis where the analysis may not overlook creative insights but also due to its frequent usage it is made to be more meaningful and most often words can be taken out of context. (Bligh et al., 2004b; Insch et al., 1997; Morris, 1994)Parameshwar (2006) gives a slightly differing and innovative concept of how transformational leaders transform themselves to a higher purpose and gives four propositions of the awakening of the leaders by (a) reframing personal suffering in the light of perceived eternal truths, (b) referencing inspiring standards of others in reflecting upon suffering, (c) reinforcing their identification with others in suffering, (d) reorienting themselves toward serving others in suffering by invoking their perceived eternal truths. 
This research is primarily based on the above four concepts of transforming the transformational leader as defined by Parameshwar and readdressed in the Bass handbook (2008) as leaders developing 'transcendental higher purposes and went beyond the ordinary by 1) exposing unresolved, disturbing human rights problems, 2) untangling false interpretations of the world; 3) breaking out of conventional solutions; and 4) making use of transcendental metaphors. The premise of the paper is therefore the above four propositions which are viewed keeping in mind Bhutto's Reconciliation.

\section{Bhutto's Transformational leadership in the 'Reconciliation'}

This research on Bhutto will be assessed on four parameters namely 1) exposing unresolved disturbing human rights problems, 2) untangling false interpretations of the world; 3) breaking out of conventional solutions; and 4) making use of transcendental metaphors.

To understand the writing of this book one needs understand the core concept of democracy as understood by Bhutto. To many Bhutto can be regarded as a 'renaissance woman' who wanted to change the precepts of Western world to the idea that Islam and democracy do not and cannot go hand in hand. She further wanted to challenge the ideology that the religion of Islam is incompatible to progress and change. Her main motive according to her book was to bridge the gap between Western democracy and democratic institutions world wide, and to make them understand that the historical processes of each of the worlds both the east and the west shapes the doctrines of the countries we live in and how the west may have inadvertently shaped the non-democratic and radical world of Islam. This research is not a treatise on democracy or Islam but an analysis of her as a leader who wanted to transform the thinking of the peoples of the world by sharing her thoughts and expertise and first hand knowledge.

\subsection{Exposing unresolved and disturbing human rights problems}

To understand this factor in leadership, one needs to understand the concept of morality in a leader. This as such can be a very difficult concept as both these terms can be defined variously. One of the finest treatises written by Mill's, $(1850,1869,1979)$ 'the Negro Question' and 'The subjection of women' speaks of human rights problems of that period. His 'Utilitarianism' espoused that happiness is the ultimate end of morality but the good for all as 'each persons happiness is as good to that person...the general happiness therefore, a good to the aggregate of all persons. To take the argument further Burns (1978) stated that transforming leaders should be more concerned with 'end values....' For Burns 'social change' and collective purpose are ideas much more important to a transforming leader.

Bass (1985) puts the interest of the organization ahead of self interest. Yet transformational leadership in politics should be assessed differently. Price (2008) debunks one myth that though in organizational studies of transformational leadership is stated to be possible, it is not so as higher values such as welfare and liberty are also different from each organization and that leaders in everyday affairs cannot 'appeal to the greater good.' Thus if such leaders can be called transformational despite having these anomalies, then so also can leaders with a different aspect of morality i.e. seeing to the greater good, can be termed transformational.

Thus in the conventional sense of transformational leadership Bhutto did possess idealized influence in the sense because she brought to the forefront a basic problem that many leaders in the Muslim world were unwilling to talk, discuss, analyze or criticize. Such leadership theory should stress on incidents where a leader has exerted exceptional influence on their followers so as to obtain favorable results (Bass, 1985; Mumford, 2006). Such leadership is based on a future oriented vision and provides meaning and direction to a particular cause (Bass, 1990; Shamir, House and Arthur, 1993). Recent research gives emphasis on ideological leadership where leaders seek followers who believe in the goals and value systems that give emphasis on the prescriptive mental model being given (Mumford, 2006). 
'Reconciliation' is replete with instances of such aspects of leadership where Bhutto tries to exert her influence on human rights problems both on the national as well as the international level. Here a selected few displaying her political philosophy cum leadership attributes are being used. In the first chapter titled 'the path back' Bhutto speaks of extremism and the manipulation at the hands of extremists. However, at the same time, she speaks of the incident of 9/11 and how many Muslims thought that it was 'payback for the domination of the west.' She speaks about how Muslims and even intellectuals are outraged and 'comfortable criticizing outsiders for the harm inflicted on fellow Muslims' but brings to the forefront that there is 'deadly silence when they are confronted with Muslim-on-Muslim violence,' and goes on to give the example of Darfur where there is an 'absence' of protests or coverage in Arab or South Asian media. She next goes on to give the incident of October 19 assassination attempt where the death of scores of her workers and the public went without sophisticated probe by the government in power. Bhutto speaks of asking for FBI and Scotland Yard forensic teams to investigate but was denied by the regime. She questions their 'insecurity and refusal.' Bhutto is of the opinion that such human right problems would go unanswered as 'extremism and militancy thrive under dictatorship,' and that permanent democratic governance would slowly mitigate such problems.

In the chapter, 'Battle within Islam' she speaks of religion being used as a tool for the perpetuation of violence by many a religion. 'Throughout history, the greatest crimes against humanity have been those carried out in the name of God, fanaticizing religious values to justify unspeakable acts against civilization,' and gives countless examples to prove her point both contemporary and otherwise. Bhutto then moves from the political scenario to the gender question in Islam, namely the lower position of women on the political, social and educational front leading to often severe human rights problems. She speaks of traditional Islam being 'prowomen's rights but that with the passage of time tribal values reasserted themselves on the populations of the Middle East, Africa and Asia. This resulted in the deterioration of gender equality and gradually narrow interpretations became the norm and perpetuated to date.

In the chapter 'the case of Pakistan,' Bhutto reiterates that during the 1960's, a new breed of academics felt that "authoritarian leaders," would be more conducive to economic development, especially in the developing countries. For Bhutto, 'Such academics failed to realize that dictators disempowered people and breed discontent. The dictators then crush first the press, to stop coverage of their repression, and then the judiciary, to stop justice for its victims.' Bhutto goes on to give instance after instance of human rights abuses which became part and parcel of the cultural political and social scenario of Pakistan. She is especially scathing of the Zia period which according to her was 'notorious for human rights abuses, including shooting protestors dead and hanging political activists.'

Later in the chapter she calls 'Pakistan today is the most dangerous place in the world,' and claims that both Balkanization and extremism have a foot hold too strong to diminish easily. She calls her country a 'tinderbox that could catch fire quickly,' but which is still a 'home of all the children of Pakistan for whom such enormous sacrifices have been made.' The chapter 'Is the clash of civilizations inevitable,' Bhutto speaks of both her world in Pakistan and the world of the West. Having experienced both worlds, Bhutto could understand how democracy was practiced in both. 'I saw that people in America took their rights for granted: freedom of speech, freedom of association, freedom of movement. In my country people were killed or imprisoned fighting for these freedoms.' She goes on to say that though she was brought up in a household where women were treated equally, but the fact remained that all around her women were not given equal treatment or importance in her home country.

\section{2) Untangling false interpretations of the world}

In the study of transformational leadership, one of the most important paradigms is to unearth and uncover the hidden truths. Thus the moral emphasis of leadership is an important aspect. The skills and morals of the leaders are inextricably intertwined and as such leadership cannot be 
defined if it fails to address concept (Ciulla, 1995). One of the basic elements of transformational leadership is to raise the level of consciousness and then give goals that can be reached through certain means (Burns, 1978).

In Reconciliation, Bhutto minces no words when she states that the Islamic world is going through difficult times both politically, culturally and ideologically. According to her, one of the most pressing problems is intellectual stagnation, especially from the point of view of economics, technology and creativity. This dearth has led to a blinding of the youth to see the problems that face them and how to circumvent such a dearth. This thus leads many to start the blame game and the fact that their sense of pride can only be reasserted and re-established by the so-called 'destroying the enemy' which symbolizes the west. She calls such an attitude as an 'opiate', an apt term that keeps the Muslims focused on 'external enemies' which in turn does not allow them to visualize the 'internal' causes of their decline both economically and intellectually. For Bhutto, 'Reality and intellectual honesty demand that we look at both sides of the coin.' She calls on the public to understand that the threat from within is far more serious and needs instant remedy than the threat from without.

She goes on to speak of the 'clash of civilizations' and the 'two critical tensions that must be reconciled' to prevent such a clash. The Muslims themselves according to her need to diffuse the clash by finding a solution to the core problems that prevent them from becoming enlightened and progressive; namely the human rights problems, the gender issues relating specifically to the place of women empowerment, the democratization process, respect for other religions and cultures and the acceptance of technology and the processes of modernity. For Bhutto, 'the building blocks of democracy-political parties, media and the judiciary-are the casualties of authoritarianism.' Dictatorship does not only breed chaos but results in 'corruption, nepotism and greed.' Accountability and instability have a field day. Only the outer semblance of authority exists which is actually a sham to hide the rotten core. Her detailed account of Pakistan's descent into authoritarian rule is a case in point.

Her vehement denial of and disagreement with Huntington's Clash of Civilizations thesis, calling it a self-fulfilling prophecy which actually provoked the confrontation it predicted, shows that Bhutto is willing to challenge existing ideas and theories and postulate that such premises of thought may have very unwarranted and unwanted results. Her detailed analysis of the 'clash thesis' shows her to challenge such a false premise on all counts.

\subsection{Breaking out of conventional situations}

In the study of transformational leadership one important element is trying to change the status quo to one that is more fulfilling and rewarding. Accordingly transformational leaders 'motivate and inspire those around them by providing meaning and challenge to their followers work' (Bass and Riggio, 2006). Such leaders envisage a future goal, a shared vision which they want their followers to share and achieve with them. The concept of visionary charismatic leadership is very important, especially in times of crises as indicated in the study of Hunt, Boal and Dodge (1999). Two further aspects came to the forefront. On the one hand followers prefer leaders who portray charisma in conditions of crises (Pillai and Meindl, 1998) and followers attributing 'self sacrificial behaviour' of the leader under crisis conditions who were more likely to portray charisma (Halverson, Holladay, Kazama and Quinoes, 2004). Another aspect of inspirational motivation is to deal with how such leader appeal to their followers. Emotions of people are appealed to and self worth is enhanced (Emrich, Brower, Feldman and Garland, 2001; House, Spangler and Woyke, 1991).

Apart from this, leaders like even Genghis Khan can be called transformational as he united warring tribes in the 12th and 13th century to create a large empire of that period (Yates, 2002). Of course perspectives differ. Bass and Steidlmeier (1998) gave a contrary argument on the ethics and character of authentic transformational leadership stating that apart from 'Western 
ethical agendas,' other issues of transcendence, trust, power and various other elements are required to actually make a leader transformational.

Bhutto in the chapter 'the path back', breaks away from stereotypical ideas of not only what many in the West have of her but also those of the East. Bhutto according to many is too westernized and often regarded as a puppet of the West. Her book however debunks this myth. Bhutto goes on to state that historically the West both promoted and discouraged the 'growth of democratic institutions through three centuries in predominantly Muslim nations'. Islam is compatible to democracy as it is, in her opinion and experience, an 'integral part of Islam'; and that those who use tactics of terror and intimidation for their own political agendas, within Islam, are committing acts that are not only 'antithetical' and abhorrent but 'prohibited' by Islam itself.

As Prime minister of Pakistan she recalls the agendas her government took in hand, like tackling education, health, housing, sanitation, infrastructure and women's rights. She broke out of conventional situations and harnessed new areas like the energy sector and power generation as well as modernization of the stock exchange and computerization. The digital and wireless communications were expanded and the most important for her was the introduction of computer education and software generation to bring Pakistan into the 21 st century. She felt that such transformative and progressive changes in all these new areas made extremists view her with trepidation. She also recalls that living in exile was not easy but sees such a situation in a different way. 'If there is a silver lining to the cloud of living away from home, it is in the people I met and the friends I made in those years.' Thus for her one of the worst situations is seen in not only a differing light, but one that fostered lasting friendships.

Later in the book she moves on to the inevitability of the Clash of Civilization thesis. She says that such a notion 'not only is unsubstantiated by Quranic reference and Islamic clerical interpretation but also plays into Islamic extremists' views that the West is disrespectful and antagonistic to Islam's beliefs and history.' By following such a notion, the West may accept the 'inevitability' of war. Also such a notion prescribes keeping Muslim nations from the threshold of progress and modernity by instilling 'xenophobia and paranoia' both within Muslim nations and the West. She calls Huntington's ideas 'flawed'. Huntington postulates that religion is a great separator; that globalization promotes xenophobia, intolerance and contempt; that economic modernization alters traditional life and people turn to fundamentalism and lastly that democracy is dangerous for the Muslim world as he focuses on conflicts between western civilization and the east. Bhutto not only goes into the details of the clash thesis but gives the differing viewpoints of both the proponents and the antagonists.

Giving her personal beliefs and experiences, Bhutto goes on to say that educational and cultural exchange does not lead to conflict but sensitizes one to differing view points, cultures, nations and civilizations. She gives not only the opinion of other scholars but shares her views. She believes in the concept of debunking the myth. 'Nothing debunks ideologically driven myths like simple facts, hard evidence.' Giving the study of Jonathan Fox (2001) and Pippa Norris and Ronald Inglehart (2002) study, Bhutto shows how Huntington's thesis is contradicted. Furthermore she comments that four civilizations in the 'clash' thesis showed more conflict within themselves than with others and this proves that there is internal conflict which does more damage than external forces. Thus Huntington's thesis 'leans in the opposite direction.' This in some way proves her thesis that the clash is not between Islam and the West but between the 'forces of moderation and modernity and the competing forces of extremism and fanaticism.'

She however postulates that 'modernization and extremism are contradictory and mutually exclusive and that modernization is related to political and religious moderation and not to fundamentalism.' Bhutto calls modernization as breeding 'dissonance and conflict' as an 'unsubstantiated assertion', as belief in such an idea would inevitably lead to and encourage 'the worst elements of human and state nature.' Her words of caution can and should be viewed in depth, especially so after her assassination. 


\subsection{Making use of transcendental metaphors}

A major chapter of Reconciliation is devoted to Islam and democracy: history and practice. However earlier on in her book her one passage comes to the forefront which depicts her reconciliatory attitude towards not only many cultures but definitely Islamic and the West / Christian dilemma. For her, true Islam can only be seen from 'the words of the Prophet himself. "God" is a translation of the Arabic word "Allah," not just the God of Islam but rather the God of monotheism, the God of all who believe in Him and believe that He is the Creator of the Universe, of this world and the hereafter.' This passage reiterates her belief that the three major monotheist religions have a strong fundamental base for greater harmony, cooperation and respect and that other factors have definitely put the wedge which creates hatred and fear towards the other.

Bhutto goes on to substantiate the view that Islam and democracy are not only compatible but is endorsed within the Quran by giving people rights (democracy), by having consultations between the rulers and the ruled (parliament) and requiring that leaders be replaced if they are self-serving (accountability). However terms like secular when translated into the Urdu language would simply mean atheist. So for her it is not necessary to use such terms which would isolate the few who have the knowledge to differentiate and understand secularism for what it stands but the ideals of democracy can be promulgated without the use of such a term. In the 'Case of Pakistan', her concluding paragraph summarizes the nation best as one which endured much with regards to movement towards democracy and democratic institutions as one 'sad chronicle of steps forward and huge steps backward.' She ends the chapter by using the words of the poet-philosopher of the Indian subcontinent Iqbal, that after that "Tyranny cannot long endure."

Apart from these Bhutto's book abounds with metaphors which can be regarded as transcendental. She uses terms that catch the spirit of the age. Earlier on in the book she speaks that intellectual dialogue in the Muslim world is not based on 'economic productivity, technical innovation or intellectual creativity' and the only pride many have today in the Islamic world is to destroy the 'enemy' or protecting the nation from western threat. She calls such thinking as 'toxic rhetoric' which instead of finding solutions to their condition actually precipitates and prolongs their backwardness. In another instance when speaking of the internal tension between the Muslims and the lack of resolution to solve such problems in a peaceful and rational way, Bhutto calls it degenerating into 'a collision course of values spilling into a clash between Islam and the West.' When speaking of the internal struggle within the Muslim world, between the moderating forces and fanatics, between democrats and dictators, between the past and the future, she calls such a struggle 'the battle for the hearts and soul of Islam.'

Later on, when commenting on the problems of dictatorships which impeded a tangible and modernizing Islamic reformation Bhutto states categorically that 'dictatorship choked the oxygen of innovation.' She gives examples of several Muslim states including Pakistan where dictatorship seemed to favour traditional hard line and extremist interpretations of Islam to give legitimacy to the rule of such dictators. She calls them as the 'theocrats' providing a fig leaf of religious legitimacy. This shows her utter contempt for such regimes world wide though she did understand their existence and use the world over.

\subsection{Findings regarding 'Reconciliation'}

As any researcher, one needs to first look at the negativities that may exist. Kakutani (2008) calls her book as 'part manifesto part spin job, part selective history and part term paper analysis.' Such comments do not emulate what Bass (1990) had to say about transformational leadership. Yet the reviewer concedes that the platform Bhutto laid out, though optimistic, where 'globalization promotes tolerance, not resentment...,' was one which was 'deeply shaken' by her untimely death. Zakaria (2008) on the other hand was of the opinion that she did not accept stereotypical ideas relating to the causes of Islamic terrorism as she does not claim that the root 
cause of the 'ill will toward the West' is primarily due to the Palestine issue nor does she spare her thoughts and comments about other Muslim countries.

Zakaria calls her discussion on Pakistan bordering on 'almost obsessive in its insistence' that the US policy has been responsible for the lack of democracy and continuous dictatorship by the military establishment in Pakistan. Yet he too realizes that the solution Bhutto offered may 'well be given a chance to work,' considering what Pakistan is facing in the coming years. Others like Rutten (2008) and French (2008) give an analysis which has more to do with her life than with her book. Rutten concludes his article questioning the fact that though many a Muslim has a home in many a Western country and form a substantial minority why is it that a substantial Jewish or Christian minority is not present in a 'single' Islamic country. Constable (2008) states that the book does contain 'flaws of self-indulgence and omission.' Such words hardly depict any form of reciprocal relationship that might exist between leader and follower in various transformational leadership studies (Einstein \& Humphreys, 2001). But Constable (2008) states that Bhutto's book 'contains a larger truth.' For her, Islam does need to find a 'moderate guiding force,' and the West does need to 'build bridges... and counter fears of a hegemonic crusade.'

Though Goraya (2009) calls her book 'vital gift for all the people', she does concede that some limitations are present, especially Bhutto's attempt to 'appease' all those who think that Muslims are radicals, overstating accomplishments of the Bhutto's and though speaking scathingly of Zia and his regime, never highlighting her political failures. Despite these demerits, the author does concede that the book has a 'visionary analysis' and a 'sound rational and heartfelt plea' for a better Pakistan. Yet for Shamsie (2008) apart from her campaigning her own families 'hagiography', the greatest disappointment about Reconciliation was the omission of the fact that it was during her tenure as Prime Minister during 1994-1996 that the Taliban actually gained control of Afghanistan and it was with the support of Pakistan and that Bhutto needs to admit to the fact.

Yet in a recent personal communication with Sardar Assef Ali Khan, former Foreign Minister of Pakistan 1993-1996, he stated that the allegations that Bhutto's government had set up the Taliban during her tenure is incorrect. The Taliban were already a force in Southern Afghanistan, especially in areas around Kandahar. They had become popular due to the mismanagement of the Northern Alliance. On the contrary, the Bhutto Government was able to cap or limit the Taliban to Southern Afghanistan through an agreement. It was only after the removal of the Bhutto government in 1996 that the Taliban moved ahead and captured Kabul and formed the government. This perspective thus gives another take on the above issue.

Yet a summary of what Bhutto herself espoused is necessary at this point. Bhutto felt that it was a time of change from old perceptions and ideas to new ones. The present literature supports the view that transformational leadership is most apt, effective and recommended during such times of chaos and turbulence (Bass, 1985; Waldman, Ramirez, House, \& Puranam, 2001). Leaders need to display such ideals. Bhutto in the book Reconciliation was of the opinion that in order to prevent the clash of civilizations the world community needs to help the Islamic world to promote the 'building blocks of democracy' by helping such nations not only hold democratic elections but also help them promote democratic governance. In other words, the world needs to come forward with not only guidance but help sustain democratic institutions. If the so-called infrastructure of democracy is strong enough, only then, especially in the Islamic world, can democracy succeed, otherwise democracy would be jeopardized in its infancy as was the norm.

To prevent the clash which seemed imminent to so many, the only way would be to promote the ideals of trade, technological exchanges, the enhancement of education and the transfer of the values of democracy. To her the clash is the result of insulation by the Muslim world and the rejection of any and everything western in the recent decades, due to a lack of trust between them and the West. The technological backwardness for centuries has perpetuated the feelings of resentment and instilled the feeling of fear. So the clash can only be resolved if the Islamic world reaches a resolution between the past and the future. Bhutto speaks of the Muslim on 
Muslim violence and states that it is lengthy battle which makes up the heart and soul of the people who practice the religion as well as religion itself. The question arises whether people will be frozen in the past with following traditional interpretations or will progress with the modern world and reconciliation with all differing interpretations is a key step towards that goal.

This idea without a doubt is a transforming idea and the goal is to change the face of Islam as it is understood today. Bhutto reiterates that by following this idea is not one whereby one loses religion but one which forms a very important cornerstone of Islam itself. Her premise is the sustainability of democracy which holds the key to development and progress and therefore weakening extremism and militancy. Bhutto's premise lies in an ambitious agenda; local, regional and international to achieve this aim. She advocates a stable and growing middle class with not only a progressive educational system but one which incorporates women's rights and empowerment. A civil society is imperative to sustain democracy and democratic institutions. Apart from this, she advocates the creation of the 'Women of the Ummah'; an organization that foresees Muslim women's rights the world over. To her the alleviation of poverty would be the key to movement away from antisocial elements in the society and to help in that aim she proposes the creation of the Muslim Investment Fund which would be structured very much in the manner of the Alaskan or Norway Fund.

Muslims the world over need to take responsibility for their own decline as it is not simply due to the effects of colonialism or the global distribution of power. She speaks of the abundance of riches in Muslim countries, if properly harvested would lead to abundance and plenty for all. She also asks the West to 'look inside and determine to what extent Muslim's perceptions of the West are justified or at least understandable.' Explaining that many Muslims the world over feel that their religion is under attack with the global war on terror one needs to clarify and help make the situation better by a proper plan to dispel such fears. Proposing two more ideas, Bhutto asks the West to support young democracies and not put added impediments in their path. She hopes the creation of an 'Association of Democratic Nations' would strengthen the bonds between such nations as well as the establishment of a Reconciliation Corps, modeled on the peace Corps which would help restore and bridge the gap between the Muslims of more advanced countries with their backward brothers.

Transformational leaders, to be effective, need to be socially committed to ideologies and ideals that can be accepted not only by their own societies but also by other communities in general. Only by realizing and bringing about development, both economic and cultural, can one hope to establish a truly transformed society. 'The standards, values and norms of the type of leadership must be defined bearing in mind the importance of ideology, culture and religion in which ethical principles and values are defined' (Aseka, 2005). All three components are needed not only in a developing nation but also in a developing region. Bhutto's Reconciliation, though ends on an optimistic note, is one which can only be achieved by action. She realizes that what is needed is to think out of the box, to be creative and committed and to be honest both among and between all peoples. What is needed is Reconciliation.

\section{Conclusion}

According to Burns (1978) leaders at times need to act as agents of social change and a transforming leader is one who changes the paradigm while a transactional is one who maintains the existing paradigm. Also transforming leaders not only raise the level of consciousness of outcomes but direct the followers on how to reach them; to try and get followers to go beyond their own self-interests and lastly to try and achieve a higher level of achievement and selfactualization for their followers. According to this concept, Bhutto without doubt in Reconciliation can be called a transforming leader. A paradigm existed whereby majority of Muslims, of not only her country Pakistan, had a tunnel vision regarding the western world but this was the paradigm of many a person the world over. Bhutto in her thesis tried to dispel this tunnel vision, asking her co-religionists to assume responsibility, to look within and not only without. But does this make her a transformational leader? 
Bass's (1985) formal transformational theory gave a four fold paradigm whereby a leader can be termed as transformational. If Bhutto's Reconciliation comes under scrutiny, her charismatic personality no doubt was felt by many. The fact that Reconciliation was on the New York Times best seller list for 4 consecutive weeks is proof enough. Ted Kennedy called her book as one with 'powerful and insightful analysis' of her struggle for democracy. Madeleine Albright stated that, 'We owe it to her-and to ourselves - to listen, comprehend, and act.' Nancy Pelosi calls her book one with 'an unshakable optimism about the future, a firm belief in the power of dialogue, and a commitment to democracy' (Bhutto, 2008). These comments show that Bhutto possessed both inspirational motivation and intellectual stimulation. A leader also serves as coaches, guides and mentors. Bhutto did offer, in her book, solutions to the problems that affected her people and the Muslim world. She did offer a new paradigm to move forward. Thus according to Bass's paradigm there is evidence of her as a transformational leader on all four counts.

This, therefore, leads us to the main question. According to the paradigm under discussion, to what extent 'Reconciliation' is demonstrative of Bhutto's transformational leadership abilities. When Kissinger (1994) cited in Bass (2008) described US diplomacy, it could be termed as transformational as it brought to the forefront the concepts and ideals of democracy, freedom from oppressive Europe where one could live with dignity and self fulfillment. As stated earlier even Genghis Khan could be called one. This brings us back to the topic under study.

Does Bhutto's book reveal transformational leadership on the four parameters discussed as a leader developing 'transcendental higher purposes and went beyond the ordinary'? The study set out to explore four dimensions of transformational leadership as assessed by Bass (2008) when discussing Parameshwar's (2006) study. As discussed earlier, the accompanying data does capture all four areas under study. Leadership by no means is an easy job. To lead any institution requires great attributes combined with a host of other qualities and capabilities. It is a life long process. Political leadership therefore becomes a much more complex and difficult role.

The first proposition is whether 'Reconciliation' exposes human rights problems. This therefore questions whether a leader understands the importance of such a concept. Bhutto does not mince words when exploring and exposing this problem from not just her own country but also the fact that many other Muslim countries face similar problems. She realizes that Islam has been portrayed as overly aggressive by some who use religion for the purposes of the acquisition of power. Some of the absolute abuses of human rights, is targeted towards women. Even Bhutto's party manifesto 2007 laid special emphasis on education, empowerment of women and the rights of the minorities with the latter area being allocated job quotas in different government agencies.

The second parameter of Bass (1990) under scrutiny is also aptly discussed. Many religio/political so-called leaders do give interpretations that justify their actions to perpetuate hatred and bigotry. She tries to alter the beliefs and thinking of others. Bhutto brings such things to the forefront stating that to follow such a paradigm is a recipe for disaster. She untangles such interpretations with evidence from a wide variety of thinkers and researchers. This aspect of having a collective sense of a mission that needs to be accomplished would not be unlike the concept of idealized influence, a key concept of transformational leadership (Avolio, Bass, and Jung,1995). To solve the above issue, Madrassah reforms were emphasized in the manifesto so as to bring all sections of society towards a sense of equality in education with the goal that no one would feel left out and hate and bigotry would not be inculcated in the minds of the young.

On the third premise, Bhutto thinks out of the box and challenges perpetuating norms and value systems and debunking many a myth. As a political leader, this must not have been easy, especially with the scenario that existed in Pakistan at that time as well as with threats to her life. This may be referred to as a form of intellectual stimulation (Bass, 1985). The literacy health corps in the manifesto where the educated youth are guaranteed a job for a year in these two sectors helps to promote education/health to the masses just to make sure the educated youth do not feel frustrated due to the lack of a job. 
On the factor of the transcendental metaphors, her book exposes varying themes that show her personal creativity and intellectual stimulation. The book also espouses a new ideology based on self analysis of the Muslim world and portrays newer devices if put into practice would lead to transforming not only Pakistani society but help in bridging the gap that exists between the haves and have-nots but also between East and West. The ability to use extremely powerful symbolism is a hallmark of her work. This concept of using such symbols to make followers change their ideas and motivate them to try and do and think differently is a major element of transformational leadership (Avolio, Waldman, \& Yammarino, 1991).

Bhutto, thus, lastly gives a new paradigm which leads to moderation, diplomacy, dialogue and reconciliation between Islamic schools of thought as well as between Islam and the West. Transformational leaders create visions, shape values and empowered change (Ford, 1991). Such leaders hope to change the world, to transform, to make it better. Bhutto hoped to do that with her book. Even her 2007 Party Manifesto promoted the five E's namely employment, education, energy, environment and equality. The book Reconciliation was her present and the Manifesto her future. Whether, her paradigm is realized, only time will tell. 


\section{References}

Anderson, (2000), cited in Bass Bernard M., and Ruth Bass, The Bass handbook of Leadership: theory research and managerial applications, The free press, New York, 2008.

Aseka Eric M., (2005), Transformational leadership in east Africa: Politics ideology and community, Fountain Publishers, Kampala

Avolio, B. J., Bass, B. M., and Jung, D. I., (1995), Multifactor Leadership Questionnaire Technical Report, Mind Garden, Redwood City, CA

Avolio, B. J., Waldman, D. A., and Yammarino, F. J., (1991), The Four l's of Transformational Leadership, Journal of European Industrial Training, Vol. 15: pp. 9-16.

Bass B. M. and Bass R., (2008), The Bass Handbook of Leadership: Theory, Research and applications, Free Press, New York

Bass, B. M., (1985), Leadership and Performance Beyond expectations, The Free Press, New York

Bass, B. M., (1990), Bass and Stogdill's handbook of leadership: theory, research and managerial applications, Free Press, New York

Bass, B. M. (1990), From Transactional to Transformational Leadership: Learning to share the vision. Organizational Dynamics, Vol.18: 19-31.

Bass B. M., and Avolio B. J., (1994), Improving organizational effectiveness through transformational leadership, Sage, thousand Oaks, CA

Bass, B. M., Avolio B. J., Jung D., and Berson Y., (2003), Predicting unit performance by assessing transformational and transactional leadership, Journal of applied psychology, Vol. 88, pp. 207-218.

Bass B. M. and Riggio R. E., (2006), Transformational Leadership, Lawrence Erlbaum associates, Publishers, London

Bennis W. G. and Nanus B., (1985), Leaders: The strategy for taking charge, Harper and Row, New York

Berelson, B., (1952), Content analysis in communication research, Free Press, Glencoe, IL 
Bhutto Benazir, (2008), Reconciliation: Islam, Democracy and the West, Simon and Schuster, London.

Bligh M. C., Kohles J. C., and Meindl J. R., (2004a), Charisma under crisis: Presidential leadership, rhetoric and media responses before and fter 9/11, Leadership Quarterly, Vol. 15, pp. 211-239.

Bligh M. C., Kohles J. C., and Meindl J. R., (2004b), Charting the language of leadership: A methodological investigation of President Bush and the crisis of 9/11, Journal of applied psychology, Vol. 83, pp. 562-574.

Burns J. M., Leadership, (1978), Harper and Row, New York

Burns J. M., (2001), Transformational Leadership, Paper presented at the Festschrift for Dr. Bernard M. Bass, Binghamton, New York

Burns J.M., (2003), Transforming Leadership, Grove Press, New York

Bryman Alan, (2004), Social research methods, Oxford University Press, Oxford

Campbell S. M., Ward A. J., Sonnenfeld J. A., and Agle B. R., (2008), Relational ties that bind: leader-follower relationship dimensions and charismatic attribution, Leadership Quarterly, 19, pp. 556-568.

Cardona P., 2000, Transcendental Leadership, The Leadership and Organization Development Journal, 21(4), pp. 201-206.

Ciulla, J. B., (1995), Leadership ethics: Mapping the territory, Business Ethics Quarterly (1), pp. 5-29.

Conger J. A., and Kanungo R. N., (1998), Charismatic leadership in organizations, Sage Pub., Thousand Oaks, CA

Constable P., (2008), Bhutto's words of warning: Reconciliation: Islam, democracy and the West by Benazir Bhutto, in Zulfiqar Halepota (Ed) Benazir Bhutto: political thinker and diplomat, Sindhica Academy, Karachi

Downtown, J.V., (1973), Rebel Leadership: Commitment and charisma in the revolutionary process, Free Press, New York

Einstein, W. O., and Humphreys, J. H., (2001), Transforming Leadership: Matching Diagnostics to Leader Behaviours, The Journal of Leadership Studies 8: No 1, 48-60

Emrich C. G., Brower H. H., Feldman J. M. and Garland H., (2001), Images in words : Presidential rhetoric, charisma and greatness, Administrative Science Quarterly, 46, pp. 527-557.

Ford L., (1991), Transforming Leadership: Jesus way of creating vision, shaping values and empowering change, Inter Varsity Press, Downers grove IL

French P., (2008), Reconciliation: Islam, democracy and the West by Benazir Bhutto, in Zulfiqar Halepota (Ed) Benazir Bhutto: political thinker and diplomat, Sindhica Academy, Karachi

Fry L. W., \& Malone P. N., (2003), Transforming schools through spiritual leadership: A field experiment. Paper presented at the annual meeting of the Academy of Management, Seattle, WA

Goleman Daniel, (1995), Emotional Intelligence, Bantam, New York 
Goraya N S., 2009, Reconciliation: Islam, Democracy \& the West (book review), A Research Journal of South Asian Studies, Vol. 24, No. 2, pp. 368-371.

Halverson S. E., Holladay C. C., Kazma S. M., \& Quinines M. A., (2004), Self-sacrificial behaviour in crises situations: The competing roles of behavioural and situational factors, Leadership quarterly, 15, pp. 211-240.

House R. J., (1977), A 1976 theory of charismatic leadership, in, Hunt J.G. and Larson L.L. (eds), Leadership: The cutting edge, Southern Illinois University Press, Carbondale, IL

House R. J., Spangler W. D., Woyke J., (1991), Personailty and charisma in the U.S. presidency: A psychological theory of leader effectiveness, Administrative Science Quarterly, 36, pp. 364-396.

House R. J., \& Aditya R. N., (1997), The Social Scientific study of Leadership: Quo Vadis? Journal of management, 23, pp. 409-473.

Howell J. M., and Shamir B., (2005), The role of followers in the charismatic leadership process: Relationships and their consequences, Academy of management review, 30, pp. 96-112.

Hughes R. L., Ginnett R. C. and Curphy G. J., Leadership: enhancing the lessons of experience, Irwin McGraw-Hill, New York

Hunt J. G., Boal K. B., Dodge G. E. (1999), The effects of visionary and crises responsive charisma on followers: An experimental examination of two kinds of charismatic leadership, Leadership quarterly, 10, pp. 423-448.

Insch G. S., Moore J. E., and Murphy L. D., (1997), Content analysis in leadership research: Examples, procedures and suggestions for future use, Leadership Quarterly, 8, pp. 1-25.

Judge T. A., and Bono J. E., (2000), Five factor model of personality and transformational leadership, Journal of Applied psychology, 85, pp. 751-765.

Judge T. A., and Piccolo R. F., (2004), Transformational and Transactional leadership: A metaanalytic test of their relative validity, Journal of Applied psychology, 89, pp. 755-768.

Kissinger H., (1994), Diplomacy, Simon and Schuster, New York

Kouzes J. M. and Posner B. Z., (1987), The leadership challenge: How to get extraordinary things done in organizations, Jossey-Bass, San Fransisco

Ladkin D., (2008), Leading beautifully: How mastery, congruence and purpose create the aesthetic of embodied leadership practice, Leadership Quarterly, 19, pp. 31-41.

Marshall Catherine and Rossman Gretchen B., (2006), Designing Qualitative Research, Sage Publications, London

Meindl J. R., (1998), Invited reaction: Enabling visionary leadership. Human Resource Development Quarterly, 9 (1), pp. 21-25.

Mill John Stuart, (1979), Utilitarianism, (ed.) George Sher, Hackett Publishing Company, Indianapolis.

Mill John Stuart, (1869), The subjection of women, http://www.constitution.org/jsm/women.htm

Mill John Stuart, 1850, The Negro Question, (http://homepage.newschool.edu/het//texts/carlyle/millnegro.htm) (retrieved July 15th 2009) 
Mio J.S., Riggio R.E., Levin S. and Reese R., (2005), Presidential leadership and charisma: the effects of metaphor, Leadership Quarterly, 16, 287-294

Morris R., (1994), Computerized content analysis in management research, Journal of Management, 20, pp. 903-931.

Mumford M.D., (2006), Pathways to outstanding leadership: A comparative analysis of charismatic, ideological and pragmatic leaders, Erlbaum, Mahwah, NJ

Mumford M.D., Antes A.L., Caughron J. J., Friedrich T.L., (2008), Charismatic, ideological, and pragmatic leadership: Multi-level influences on emergence and performance, Leadership Quarterly 19, 144-160

Mumford M.D., and Van Dorn J.R., (2001), The leadership of pragmatism: Reconsidering Franklin in the age of charisma, Leadership Quarterly, 12, pp. 274-309.

Nemanich A.L., Keller R.T., (2007), Transformational Leadership in an acquisition: A field study of employees, Leadership Quarterly, 18, pp. 49-68.

Northouse Peter G., (2007), Leadership Theory and Practice, Sage Publications Inc, India

Pawson Ray, (1995), Methods of content/document/media analysis in Haralambos M,(ed.) Developments in Sociology, Vol. 11, Causeway Press, Ormskirk

Pepper A., 2003, Leading professionals: A science, a philosophy and a way of working. Journal of Change Management, 4 (1), pp. 349-361.

Pillai R., and Meindl J. R., (1998), Context and charisma: A 'meso' level examination of the relationship of organic structure, collectivism, and crisis to charismatic leadership, Journal of Management, 24, pp. 643-671.

Podsakoff P. M. Mac Kensie S. B. and Bommer M., (1996), Transformational leader behaviours ad substitutes for leadership as determinants of employee satisfaction, commitment, trust and organizational citizenship behaviors, Journal of Management, 22, pp. 259-298.

Price Terry L., (2008), Leadership Ethics: An Introduction, Cambridge University Press, New York

Riessman Dr. Catherine Kohler, (2008), Narrative methods for the Human Sciences, Sage publications Inc, United Kingdom

Rutten T., (2008), Review Benazir Bhutto's last book seems selectively revealing in Zulfiqar Halepota (Ed) Benazir Bhutto: political thinker and diplomat, Sindhica Academy, Karachi

Sanders J. E., Hopkins W. E., and Geroy G. D., (2002), Transcendental Leadership Theory: Exploring the spiritual dimensions of leadership. Paper presented at the annual meeting of the Academy of Management, Denver, CO

Sardar Assef Ali Khan., (2010), Personal communication with Dr. Javaid Laghari, May 10, 2010

Sashkin M., (1988), The visionary leader, in J.A. Conger and R.N.Kanungo (Eds), Charismatic Leadership: The elusive factor in organizational effectiveness, Jossey-Bass, San Francisco

Seyranian V., and Bligh M.C., (2008), Presidential charismatic Leadership: Exploring the rhetoric of social change, Leadership Quarterly, 19, pp. 54-76. 
Shamir, B., House R J., \& Arthur M. B., (1993), The motivational effects of charismatic leadership: A self concept based theory, Organizational Science, 4, 577-594

Shamsie K., (2008), Benazir's Blueprint,The Guardian, www.guardian.co.uk/books/2008/feb/16/politics

Stoner, J. A. R, \& Freeman, R. E., (1992) Management, Prentice-Hall of India, New Delhi

Tichy N and Devanna M.A., (1986), The transformational leadership, Wiley, NewYork

Treviño L K., Brown M., \& Pincus-Hartman L., (2003), A qualitative investigation of perceived executive ethical leadership: Perceptions from inside and outside the executive suite. Human Relations, 56 (1).

Waldman D., Javidan M., \& Varella P., (2004), Charismatic leadership at the strategic level: A new application of upper echelons theory, Leadership Quarterly, 15, pp. 355-380.

Waldman D. A., Ramirez G. G., House R. J., and Puranam P., (2001), Does Leadership Matter?: CEO Leadership Attributes and Profitability under Conditions of Perceived Environmental Uncertainty, Academy of Management Journal Vol.44: pp. 134-143.

Weber M., (1947), The theory of social and economic organization, (trans T Parson) Free Press, New York

Whetstone J. T., (2002), Personalism and Moral Leadership: The servant leader with a transforming vision, Business Ethics, A European Review, 11 (4), pp. 385-393.

Yates M., 2002, Genghis Khan, Leader Values, www.leadervalues.com/Content/detail.asp?ContentDetaillD=799

Yukl G., and Howell J. M., (1999), Organizational and contextual influences on the emergence and effectiveness of charismatic leadership, Leadership Quarterly, 10, 257-283

Zakaria F., (2008), Bhutto and the future of Islam, in Zulfiqar Halepota (Ed) Benazir Bhutto: political thinker and diplomat, Sindhica Academy, Karachi. 